\title{
A review of ureteral injuries after external trauma
}

\author{
Bruno MT Pereira", Michael P Ogilvie ${ }^{1}$, Juan Carlos Gomez-Rodriguez ${ }^{1,2}$, Mark L Ryan ${ }^{1}$, Diego Peña², \\ Antonio C Marttos', Louis R Pizano', Mark G McKenney ${ }^{1}$
}

\begin{abstract}
Introduction: Ureteral trauma is rare, accounting for less than $1 \%$ of all urologic traumas. However, a missed ureteral injury can result in significant morbidity and mortality. The purpose of this article is to review the literature since 1961 with the primary objective to present the largest medical literature review, to date, regarding ureteral trauma. Several anatomic and physiologic considerations are paramount regarding ureteral injuries management.

Literature review: Eighty-one articles pertaining to traumatic ureteral injuries were reviewed. Data from these studies were compiled and analyzed. The majority of the study population was young males. The proximal ureter was the most frequently injured portion. Associated injuries were present in $90.4 \%$ of patients. Admission urinalysis demonstrated hematuria in only $44.4 \%$ patients. Intravenous ureterogram (IVU) failed to diagnose ureteral injuries either upon admission or in the operating room in $42.8 \%$ of cases. Ureteroureterostomy, with or without indwelling stent, was the surgical procedure of choice for both trauma surgeons and urologists (59\%).

Complications occurred in $36.2 \%$ of cases. The mortality rate was $17 \%$.

Conclusion: The mechanism for ureteral injuries in adults is more commonly penetrating than blunt. The upper third of the ureter is more often injured than the middle and lower thirds. Associated injuries are frequently present. CT scan and retrograde pyelography accurately identify ureteral injuries when performed together. Ureteroureterostomy, with or without indwelling stent, is the surgical procedure of choice of both trauma surgeons and urologists alike. Delay in diagnosis is correlated with a poor prognosis.
\end{abstract}

\section{Introduction}

\section{Background}

The proper management of a trauma victim is an increasingly relevant topic of discussion due to international warfare and the growing domestic incidence of traumatic injury. According to the Center for Disease Control and Prevention (CDC), trauma is the leading cause of death in children and young adults and overall is the fifth leading cause of death in the United States [1]. The World Health Organization classifies trauma as the $9^{\text {th }}$ leading cause of death worldwide [2,3].

Ureteral trauma was first reported in 1868 by Alfred Poland when he described the first case of disruption from blunt trauma [4]. The patient was a 33-year-old woman who died 6 days after being pinned between a platform and a railway carriage. At autopsy, in addition to many other injuries, the right ureter was avulsed

\footnotetext{
* Correspondence: bpereira@med.miami.edu

'DeWitt Daughtry Family Department of Surgery, Leonard M. Miller School of Medicine, University of Miami/Jackson Memorial Hospital, Ryder Trauma Center, Miami, FL, USA
}

(c) 2010 Pereira et al; licensee BioMed Central Ltd. This is an Open Access article distributed under the terms of the Creative Commons Attribution License (http://creativecommons.org/licenses/by/2.0), which permits unrestricted use, distribution, and reproduction in any medium, provided the original work is properly cited. below the renal pelvis [5]. Henry Morris described the first ureteral procedure in 1904, when he performed an ureterectomy on a 30-year-old male who "fell from his van catching one of the wheels across his right loin" [6]. In both cases, the ureteral injury was missed upon injury and repair, secondary to a single low-velocity penetrating missile, in 1981 [7].

Genitourinary (GU) trauma is often overlooked in the setting of acute trauma due to immediate, life-threatening injuries taking precedence, but accounts for roughly $10 \%$ of all injuries seen in the emergency room. Ureteral trauma is uncommon, accounting for less than $1 \%$ of all urologic trauma [8]. However, a missed ureteral injury can result in significant morbidity and mortality.

The rationale for this article is to review the literature since Zufall et al published the first indexed series on ureteral trauma in 1961 [9], with the primary objective to present the largest review of the literature concerning ureteral trauma. This article summarizes the background of ureteral traumatic injuries, provides a review of the admission. Kirchner reported the first bilateral ureteral 
surgical approaches to their treatment and proposes an updated management algorithm.

\section{Anatomic and physiologic considerations}

Ureteral injuries (UI) due to trauma are rare as the ureter is well protected in the retroperitoneum by the bony pelvis, psoas muscles and vertebrae $[10,11]$. The left ureteropelvic junction is posterior to the pancreas and ligament of Treitz. The inferior mesenteric artery and sigmoidal vessels cross in front of the left ureter at its inferior pole. On the right side, the ureter lies posterior to the duodenum and just lateral to the inferior vena cava, with the right colic and ileocolic vessels crossing in front. Due to this protection, injuries to the ureter are typically accompanied by significant collateral damage and management is dictated by the severity of associated injuries [10-13]. Anatomically, the ureter is 22 to $30 \mathrm{~cm}$ in length and is divided into three portions: the proximal ureter (upper) is the segment that extends from the ureteropelvic junction to the area where the ureter crosses the sacroiliac joint, the middle ureter courses over the bony pelvis and iliac vessels, and the pelvic or distal ureter (lower) extends from the iliac vessels to the bladder (Fig. 1). The terminal portion of the ureter may be subdivided further into the juxtavesical, intramural, and submucosal portions. The surgeon must pay special attention to the gonadal and iliac vessels, as they cross the ureter at the posterior and anterior levels respectively, descending into the pelvis.

The ureter's blood supply comes from the ureteral artery, which runs longitudinally along the ureter and lacks collateral flow in $80 \%$ of patients. The upper third of the ureteral artery is supplied by the aorta and renal artery, while branches of the iliac, lumbar and vesicular arteries supply the middle and lower thirds of the ureter. In the abdomen the blood supply is medial, while in the pelvis the blood supply is lateral with the richest blood supply to the pelvic ureter. From a surgical standpoint, knowledge of the vascular supply to the ureter is crucial prior to any manipulation and subsequent repair. This tenuous blood supply must be considered when dealing with complex repairs of significant injuries and strict adherence to the principles of ureteral repair can prevent complications such as leak, renal injury and in some cases, death [14-17].

Histologically, the ureter consists of three distinct layers. The first is an inner mucosal layer of transitional epithelium covered by lamina propria. The inner layer produces mucosal secretions to protect itself from urine. The second or middle layer is muscular and consists of both longitudinal and circular layers of smooth muscle, which help propel urine forward by peristalsis. The outer (adventitial) layer consists of areolar connective tissue and contains nerves, blood vessels and lymphatic vessels.
No continuous lymph channels extend from the kidney to the bladder. Lymphatic drainage from the ureter drains to regional lymph nodes including the common iliac, external iliac and hypogastric lymph nodes.

The ureter is a dynamic organ rather than a simple conduit through which urine flows. It conducts urine from the renal papillae to the ureteral orifices in the bladder irrespective of the spatial orientation of the body. However, when the urinary transport system is disturbed, gravity may influence directional flow [18]. Three major functions are attributed to the renal pelvis and ureters: absorption, dynamics, and tonus. Absorption is minimal and unaffected by repair of the ureter and its consequent function. The dynamics reflect the synchronous and progressive contractile movement of the ureter away from the ureteropelvic junction (UPJ) to the ureter-vesical orifice, produced by the intrinsic automaticity of the ureteral musculature $[14,18]$. Tonus of the ureter is the degree of contraction that the ureteral wall assumes for a given rate and volume of urinary output. Tonus initiates detrusor action at a certain volume, thus perpetrating the cyclical undulations. When a ureter is damaged by penetrating or blunt trauma, peristalsis beyond the injury ceases. Tonus is decreased in the ureter, proximal to the injury, due to stretching from the increased volume of urine in this segment. This increased volume of urine is the result of detrusor action being halted at the damaged (inert) segment of the ureter [19]. Thus, urine volume, diuresis and distention are the main modulators of peristalsis along with the sympathetic and parasympathetic nervous system; however, prostaglandins and tachykinins also play a role.

\section{Wound Ballistics}

Ballistics is the study of the motion of projectiles in flight and wound ballistics is the study of the motion of missiles within the body and their wounding capacity. The trauma surgeon must be knowledgeable in both ballistics and wound ballistics in order to better understand the mechanism of injury.

The ureter may be injured by penetrating (i.e. gunshot or stab wounds) or blunt trauma. The relative predominance of ureteral injury associated with gunshot wounds is reflected in the characteristics of the permanent cavity trajectory of the bullet and the missile blast injury (temporary cavity). The bullet can damage the ureter via direct transection or the blast injury caused by the missile may disrupt the intramural blood supply, resulting in ureteral necrosis. Fortunately, fewer than $3 \%$ of gunshot injuries involve the ureters [11].

The powerful stretch due to blast effect (temporary cavity) caused by low velocity missiles over the ureter and adjacent tissues may not be immediately apparent during laparotomy or by extravasation of contrast during imaging. However, the blast contusion can seriously 


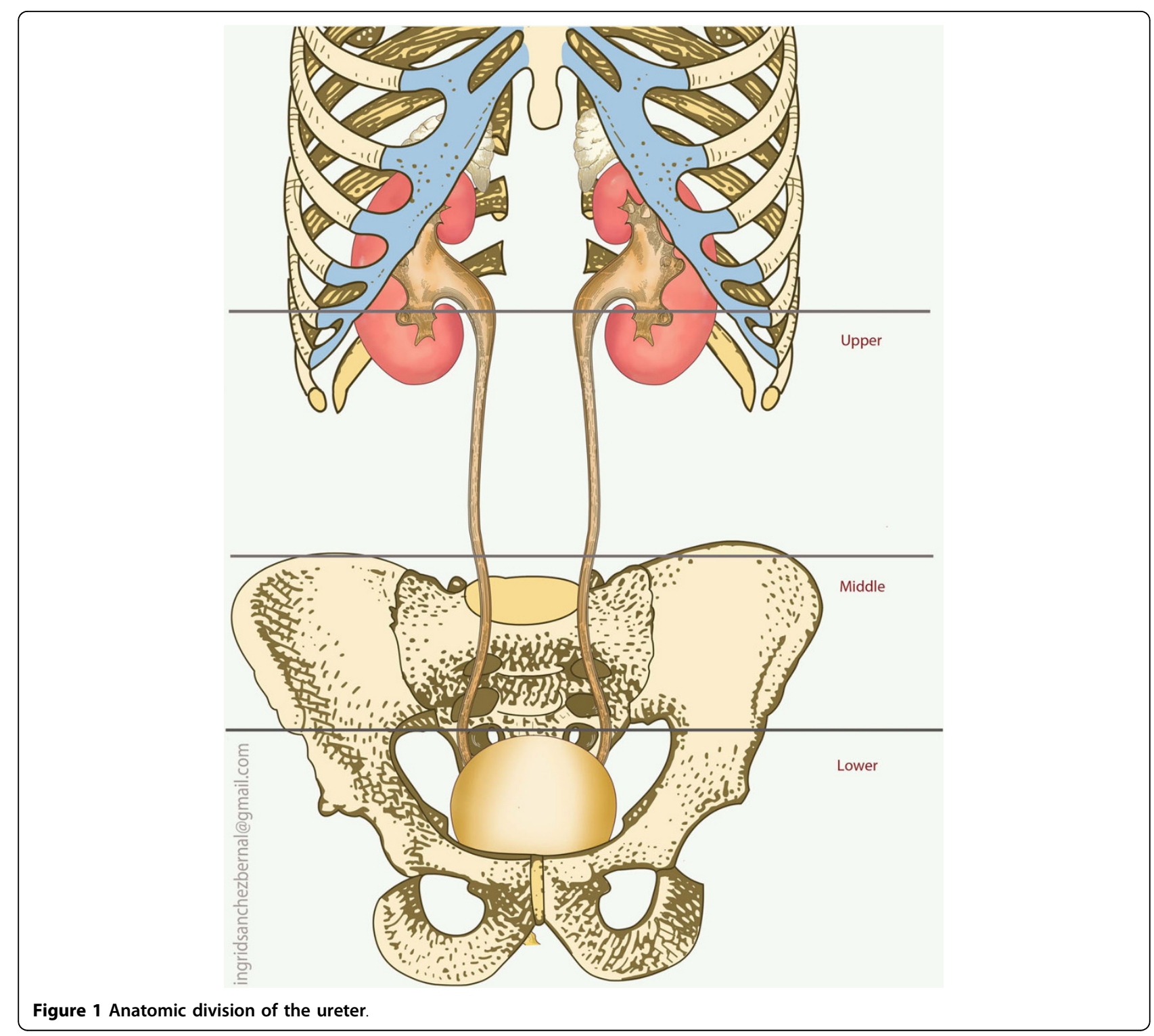

damage the small ureteral blood vessels producing thrombosis and ischemia, which eventually results in delayed necrosis and complications (i.e. urine leakage and ureteral fistula). Therefore, the surgeon must be aware that the integrity of the ureter may be in jeopardy for several days post-injury [7,16,20-25].

As the incidence of trauma has increased over the years, so too has the incidence of ureteral injury. Additionally, as the power of the weapons utilized increases, the characteristics of penetrating trauma continue to evolve. High velocity missile wounds are much more commonplace and are a challenging entity for trauma surgeons. Gunshot wounds are mainly low velocity and typically create only localized damage. In contrast, the significant kinetic energy of high velocity missiles result in extensive damage to the surrounding tissue creating temporary cavities in the order of 30 to 40 times larger than the size of the permanent cavity. This extremely high pressure can cause irreversible damage to adjacent tissues and it is imperative that the trauma surgeon be aware of these devastating effects $[25,26]$.

\section{Literature review Methods}

The following electronic databases were used to identify publications for this review: Bireme/Lilacs (Latin America and Caribbean Center on Health Science Information, Pan American Health Organization - Virtual Health Library), Cochrane Library (Injuries Group's), Embase, Medline, Pubmed and Springer Link.

Key words used: "ureter", "ureteral", "traumatic", "trauma", and "injury". 
Eighty-one articles were initially identified. Publications were excluded if they did not mention data on demographics, type of trauma or clinical/surgical approach. Articles were also excluded if they were not written in English, Spanish or Portuguese. Overall, only four articles were excluded with the remaining articles compiled into Additional file 1 - Table S1.

The medical literature review table (Additional file 1 Table S1) is organized by year of publication in descending order. Authors, study design, objectives, incidence (demographics, type of injury, ureter injured portion), admission diagnostics (urine analysis, IVU, CT scan, RPG, intraoperative diagnosis), surgical technique and complications (early and late) were compiled. Of note, missed injuries were considered a late complication.

\section{Results}

Literature search identified 77 retrospective reviews with a total of 1021 patients. All articles were classified as level of evidence (LOE) 3 or 4 (retrospective studies and case reports).

Of all compiled patients, $83.4 \%( \pm 28.5)$ were males and the average age was 23.2 years old $( \pm 12.1)$, reflecting young male predominance in violent trauma.

The majority of ureteral injuries $(61.1 \% \pm 45.7)$ were caused by a penetrating mechanism. Proximal ureteral injury occurred at a rate of $59.7 \%( \pm 37)$, while mid and distal injuries occurred $25.6 \%( \pm 30.4)$ and $20.8 \%$ ( \pm 24.4) of the time, respectively.

Associated injuries were present in $90.4 \%( \pm 26.2)$ of patients, indicating that ureteral injuries often occurs as part of a myriad of problems associated with significant trauma. Small and/or large bowel injuries were most commonly involved in conjunction with ureteral trauma $(96 \% \pm 21.5)$.

When performed, admission urinalysis demonstrated hematuria in only $44.4 \%$ ( \pm 36.3$)$ of patients. Intravenous ureterogram (IVU) failed to diagnose ureteral injuries either upon admission or in the operating room in $42.8 \%$ $( \pm 38)$ of cases. However, when a CT scan and retrograde pyelogram were performed together they were able to accurately identify ureteral injuries - in an early or delayed setting, $88.3 \%( \pm 28.2)$ of the time. Intraoperative diagnoses were made in $62 \%$ ( \pm 38.8 ) of cases.

Ureteroureterostomy, with or without indwelling stent, was the surgical procedure of choice of both trauma and urology surgeons $(59 \% \pm 34)$.

Complications occurred in $36.2 \%( \pm 34)$ of cases, including retroperitoneal abscesses, infected urinomas and fistulas; these were usually secondary to a delay in diagnosis. Missed ureteral injuries were reported in $38.2 \%( \pm 39.5)$ of the cases. The associated mortality rate of the study population was $17 \%$, although the contribution from the ureteral injury is difficult to quantify.

\section{Diagnosis and management}

In diagnosing ureteral injuries from trauma, the most important factor is a high index of suspicion [27]. Typically there are no classic signs or symptoms for ureteral injuries, but should be suspected in all cases of penetrating abdominal injury and in cases of blunt deceleration trauma, particularly in children in whom the kidney and renal pelvis can be torn from the ureter, secondary to their hyper-extensible vertebral column $[10,11,28]$. Although some authors advocate that hematuria is the hallmark of any GU lesion, it is present in only half $(43 \%)$ of those with UI, indicating that hematuria is not a sensitive indicator of ureteral trauma $[10,13,17,28-30]$. Therefore, any patient that presents with gross hematuria, flank pain or ecchymosis should undergo more extensive investigation $[16,20,28,29]$.

Unfortunately, there is no imaging modality best suited to diagnose acute ureteral injury. The use of ultrasound has gained widespread use in trauma but has proven unreliable in evaluating ureteral injuries, particularly because of their small caliber and retroperitoneal location. According to the European Association of Urology guidelines, computed tomography (CT) and an intra-operative single-shot intravenous pyelogram (IVP) are the most useful diagnostic tools, but some authors have argued against the reliability of singleshot IVP [10,11,17,30-34]. Complete IVP (which includes all excretory phases) has proven a reliable study in the stable trauma patient for diagnosing ureteral trauma but is often impractical given the precarious nature of most trauma victims [35-39]. Retrograde pyelography is believed to be the most accurate method of diagnosis but is not feasible in hemodynamically unstable patients. For the stable patient who can undergo a CT scan, delayed excretory phase images have the benefit of not only showing extravasation of contrast media from the ureteral injury, which may be subtle, but can also illustrate accompanying lesions, particularly involving the kidney [12,30,32,33]. In the delayed setting, a CT may also diagnose missed ureteral injuries (i.e. ascites, urinomas, hydronephrosis and contrast extravasation).

The American Association for the Surgery of Trauma (AAST) created a grading scale of ureteral injuries (UI) (Table 1) [40] and surgical management has been shown to be highly dependent on the AAST grade, site of the injury, associated injuries and whether the ureteral injury is diagnosed in the acute or delayed setting $[10-13,17,19]$.

The primary objective of ureteral repair is preservation of renal function. Hence, the most important factor in the management of these injuries is to maintain drainage of urine from the kidney and to prevent the 


\begin{tabular}{cc}
\hline Grade & Description of Injury \\
\hline I & Hematoma only \\
III & Laceration $<50 \%$ of circumference \\
IV & Laceration $>50 \%$ of circumference \\
V & Complete tear $<2 \mathrm{~cm}$ of devascularization \\
\hline
\end{tabular}

formation of urinoma and abscess [19]. The algorithm for external ureteric trauma is shown in Fig 2[30].

Injuries identified in the early phase may be surgically repaired over a stent using fine absorbable sutures, assuming a tension free, healthy tissue anastomosis can be achieved. Large ureteric injuries present a significant problem, especially in the upper and mid zones, as they may require significant reconstruction $[13,17,19,36,41-46]$. Successful repair methods for acute ureteric injuries are based on certain principles: ureteric debridement and careful mobilization, spatulated, tension-free, water-tight anastomosis over a stent (5-0 absorbable suture under magnification), isolation of the ureteric repair from associated injuries and adequate drainage of the retroperitoneum $[19,30,36,42,43]$.

Some authors oppose the use of indwelling stents in the setting of ureteral trauma, citing such potential problems as obstruction, stricture formation, inflammation from the foreign body, stent migration and patient discomfort, however, this is not supported by the current surgical literature $[36,47]$. Other authors have argued that the benefits of the ureteral stent in the management of this injury far outweigh the potential risks and advocate use of a stent, especially in the setting of high-velocity gunshot wounds $[12,37,38,41,48-51]$.

The pertinent reconstructive options, based on location are presented in table 2 (Figs 3, 4, 5, 6).

Failure of prompt diagnosis can lead to several complications including renal failure, sepsis and death. More common complications include the formation of urinomas, periureteral abscess, fistulas and strictures. However, these complications are readily preventable and can occur less than $5 \%$ of the time with proper stenting and/or placement of a nephrostomy tube $[10,17,43]$. Surgical repair is typically recommended for delayed complications such as fistulas and strictures.

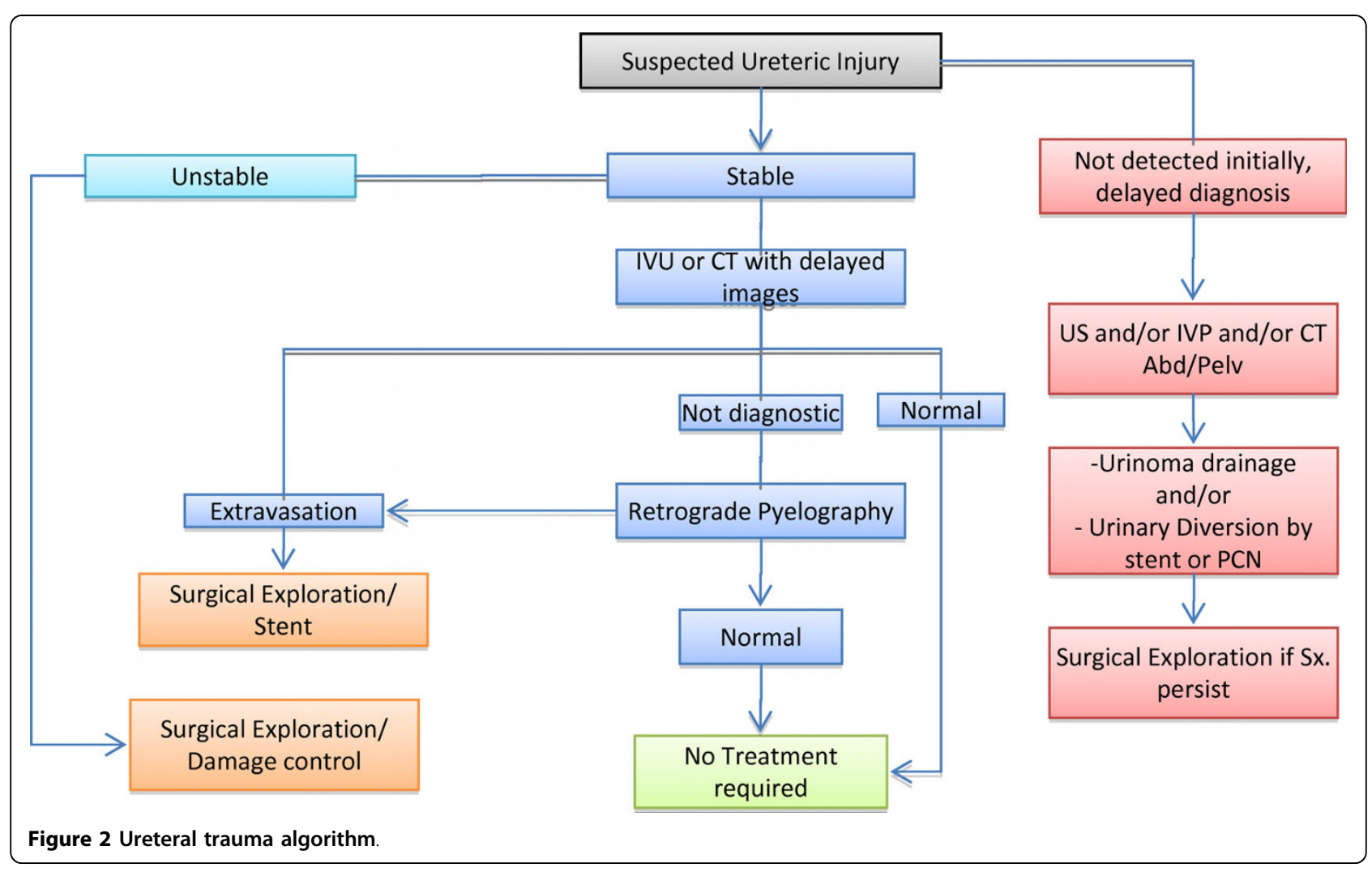


Table 2 Pertinent reconstructive options, based on location

\begin{tabular}{cl}
\hline Upper third & Uretero-ureterostomy (Fig. 3) \\
& Ureteropyelostomy \\
\hline Middle third & Uretero-ureterostomy \\
& Transuretero-ureterostomy (Fig. 4) \\
& Anterior wall bladder flap (Boari) (Fig. 5) \\
\hline Lower third & Ureteroneocystostomy (direct reimplantation) \\
& Ureteroneocystostomy (psoas hitch) (Fig. 6) \\
\hline
\end{tabular}

The early diagnosis of ureteral injury is extremely important and directly related to the patient's prognosis $[8,24,25,30,41,52-62]$. In the articles reviewed, late diagnoses including missed injuries were correlated with higher rates of morbidity and mortality.

Other factors that might confound the diagnosis of ureteral trauma are: pre-existing renal pathology, associated injuries, acute and chronic renal failure, arteriovenous fistula and renovascular hypertension [45].

\section{Special Considerations}

In the event of a complete loss of the ureter, the various surgical options have been well documented; these include an appendiceal interposition (children delayed), an ileal segment interposition (delayed), or autotransplantation [63-69].
The vermiform appendix has been used as a conduit in some cases (adults or children) and is another surgical option for complete ureteric loss in the non-acute trauma setting. The appendix is similar to the ureter in caliber and mucosal surface area. Additionally, there is no significant absorption of sodium chloride or urea and hence electrolyte disturbances are not seen (as has been described with ileal interposition grafts). The reported disadvantages of using the appendix are stenosis, anastomotic dehiscence, fistula formation and inadequate length, which may exclude its use in significant ureteral loss. Anastomotic breakdown is reported to have a higher incidence in isoperistaltic interposition. Antiperistaltic interposition is therefore recommended to theoretically reduce torsion of the mesoappendix and thus prevent further vascular compromise [63-69].

An ileal interposition, much like the appendiceal interposition, is not performed in the acute setting due to the need for bowel preparation. Despite reported success rates of up to $81 \%$, several authors condemn this approach for its high complication rate $[29,30,61,70-75]$. Reported complications include urosepsis, vesicoileal reflux, obstruction, excess mucus formation resulting in obstruction secondary to the formation of mucus plugs,

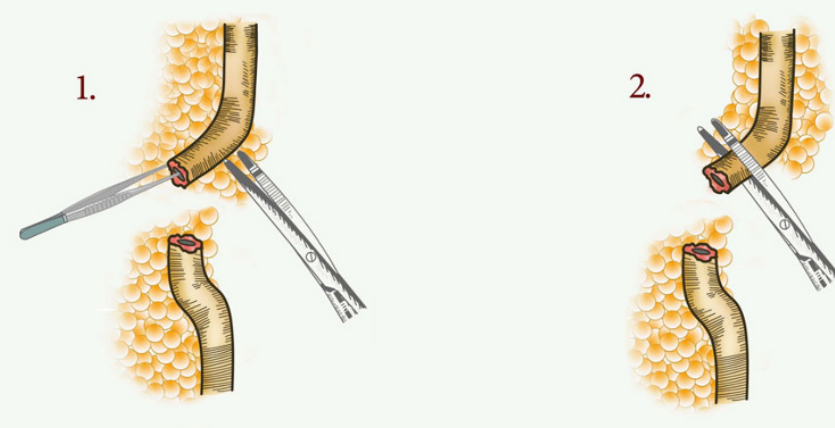

3.

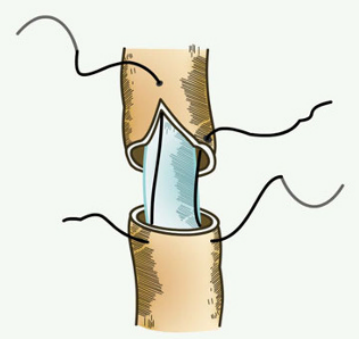

4.

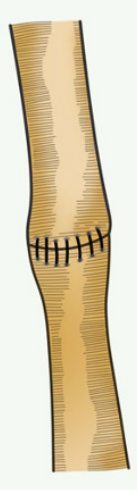

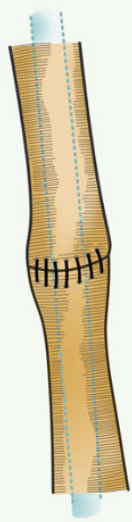

Figure 3 Uretero-ureterostomy. 


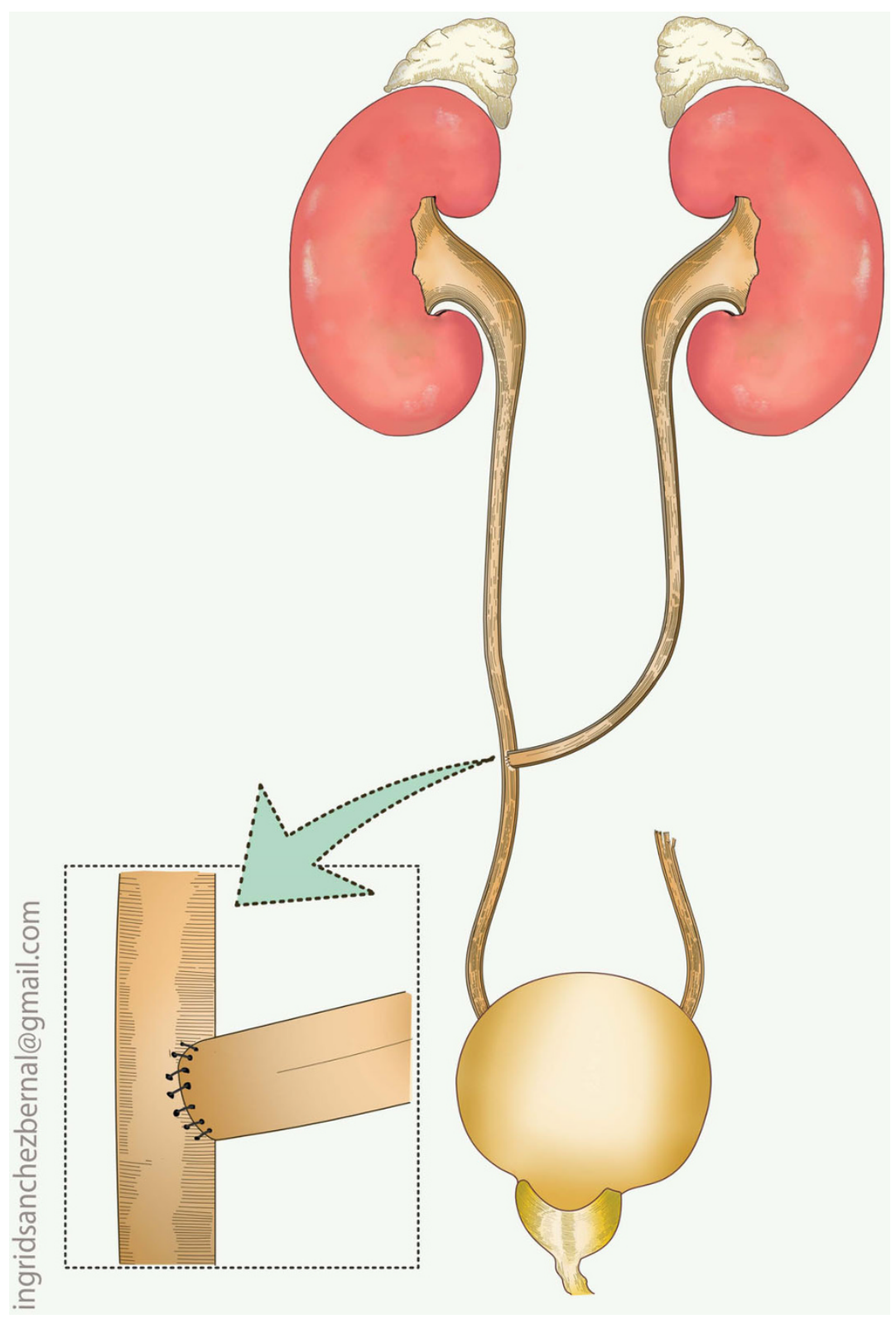

Figure 4 Transureteral ureterostomy.

urolithiasis and electrolyte disturbances, most commonly in the form of metabolic acidosis [70-75].

Autotransplantation involves relocating the ipsilateral kidney to the pelvis; the renal artery and vein are then anastomosed to the iliac vessels and the healthy ureter or renal pelvis is anastomosed to the bladder. Autotransplantation is less desirable than use of the appendiceal or ileal conduit for massive ureteral loss due to its complex nature.

Fibrin sealant is being applied more often in various surgical fields, including urology. It has proven to be safe in trauma and to reinforce ureteral anastomosis
[76-79]. Fibrin glue has not been shown to have adverse effects in rabbit models [80].

\section{Conclusion}

Ureteral injuries (UI) due to trauma are unusual. However, failure to take this type of injury into consideration can have dire consequences, as complications from missed injuries are a cause of severe morbidity and mortality. This is the largest review of the literature regarding traumatic ureteral injuries and from this several things are evident. First, penetrating injuries are more common than blunt ureteral injuries in adults. Second, the upper third of the 


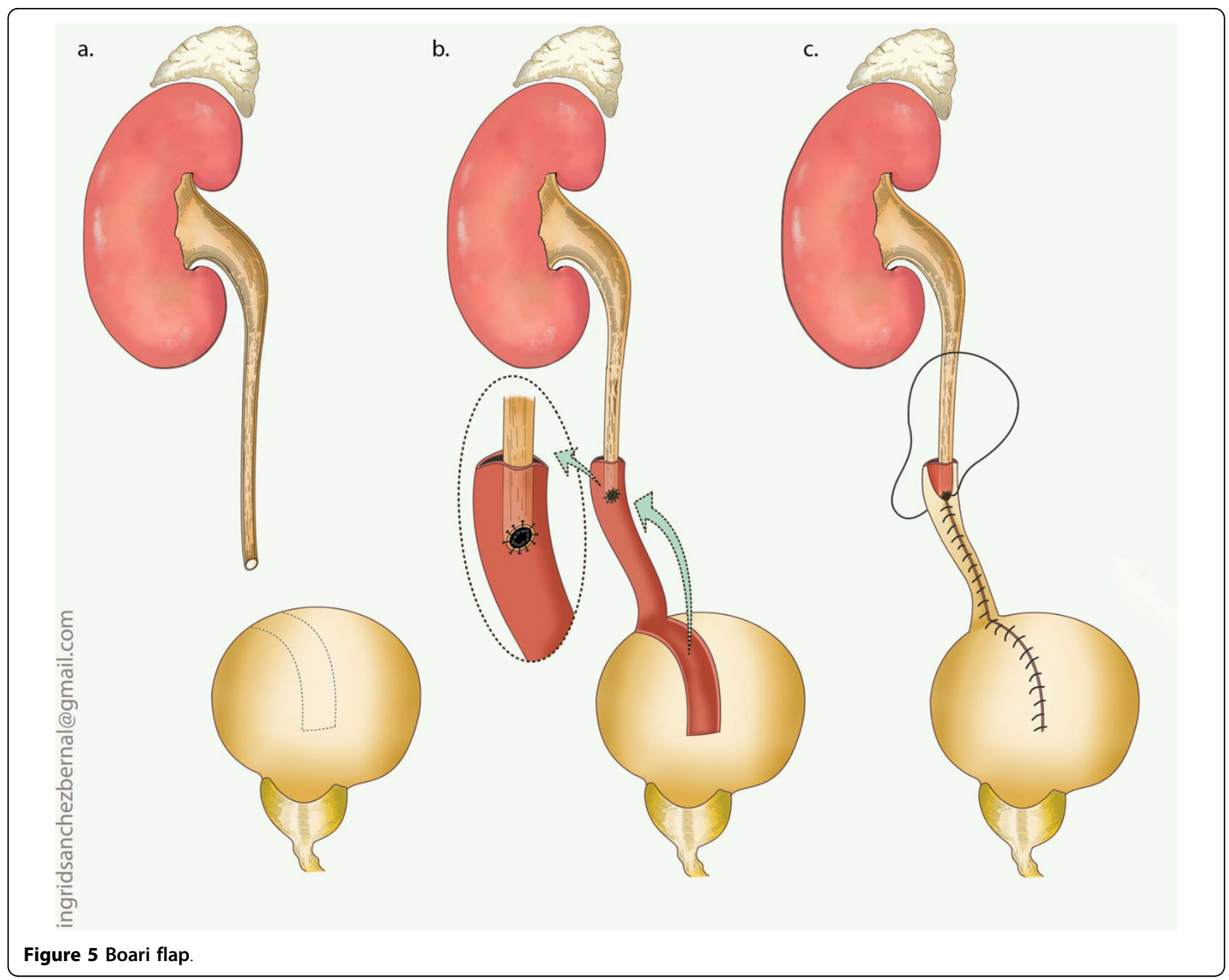

ureter is more often injured than the middle and lower third. Third, associated injuries are frequently present. Fourth, CT scan and retrograde pyelography accurately identify ureteral injuries when performed in concert. Fifth, ureteroureterostomy, with or without indwelling stent, is the surgical procedure of choice of both trauma surgeons and urologists alike. Sixth and lastly, delay in diagnosis is associated with a worse prognosis.

Additional file 1: Ureteral Injuries Medical Literature Review. The medical literature review table is organized by year of publication in descending order (2008 -1961). Authors, study design, objectives, incidence (demographics, type of injury, ureter injured portion), admission diagnostics (urine analysis, IVU, CT scan, RPG, intraoperative diagnosis), surgical technique and complications (early and late) were compiled [7-9,11,13,1619-21,25,27-29,32-36,39,42,48,49,51-53,55-59,61,62,64, 67,69,81-119].

Click here for file

[http://www.biomedcentral.com/content/supplementary/1757-7241-18-6S1.DOCX]

\section{Acknowledgements}

We appreciate the comments and suggestions of Dr. Kenneth Proctor, PhD. We are especially in debt to him and his unique way of conducting research.

We also appreciate the kind gesture of Dr. Steven Brandes, MD, for granting permission to use and adapt part of his previously published data.

\section{Author details}

'DeWitt Daughtry Family Department of Surgery, Leonard M. Miller School of Medicine, University of Miami/Jackson Memorial Hospital, Ryder Trauma Center, Miami, FL, USA. ${ }^{2}$ Universidad Militar Nueva Granada, Hospital Militar Central, Servicio de Cirurgia General, Bogotá, DC, Colombia.

\section{Authors' contributions}

BMTP had overall responsibility for the study including conception, design and intellectual content, collection, analysis and interpretation of data; drafting and revision of the manuscript, figures and tables.

MPO participated in the collection, analysis and interpretation of data; revision of the manuscript, figures and tables.

JCGR participated in the analysis and interpretation of data; revision of the manuscript. Essential participation in the manuscript lay out, drafting figures and tables.

MLR participated in the collection, analysis and interpretation of data; revision of the manuscript, figures and tables. 


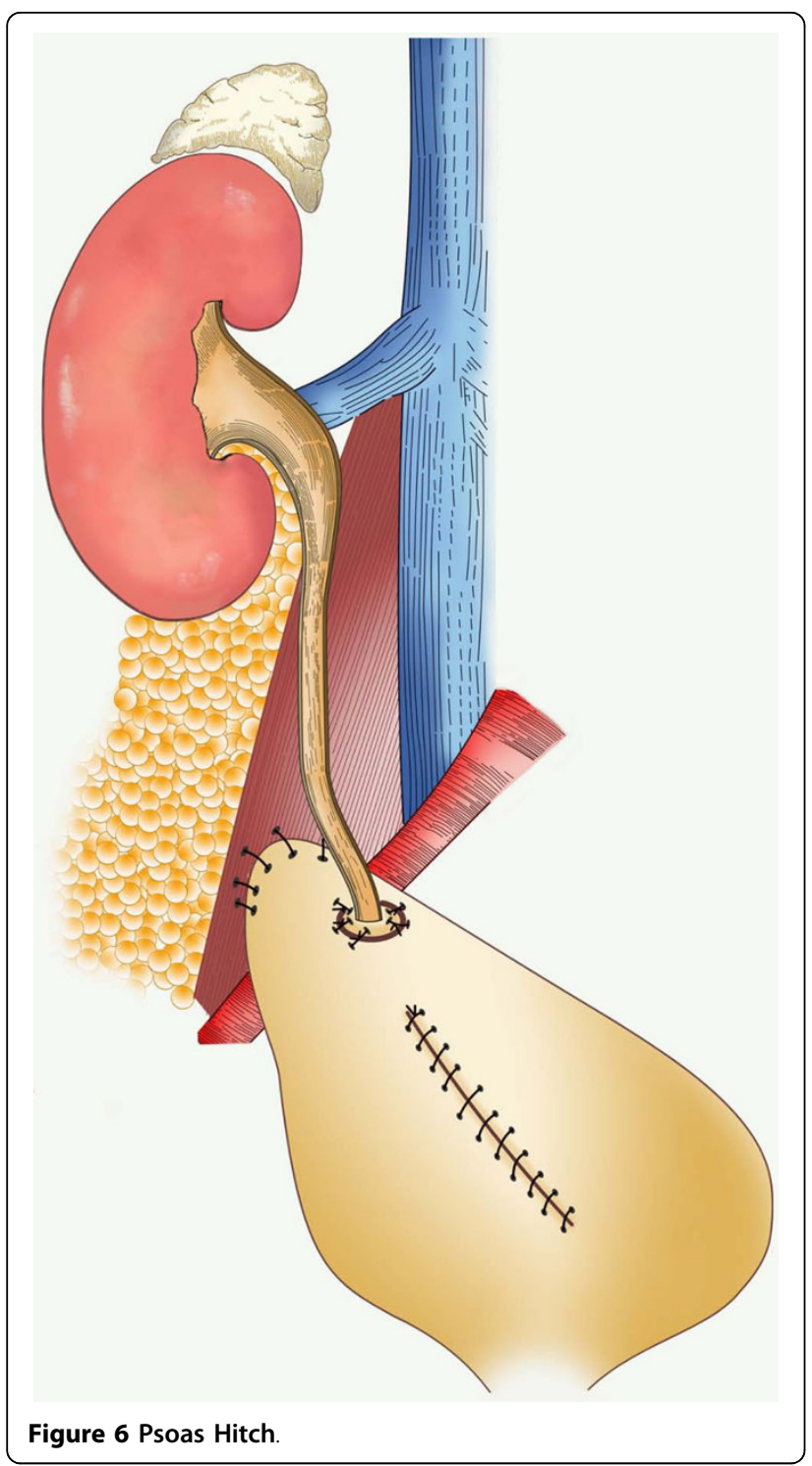

DP participated in the collection of data.

ACM participated in the revision of the manuscript, figures and tables. LRP participated in the revision of the manuscript, figures and tables. MGM participated in the intellectual content; revision of the manuscript, figures and tables.

All authors read and approved the final manuscript.

\section{Competing interests}

The authors declare that they have no competing interests.

Received: 16 December 2009

Accepted: 3 February 2010 Published: 3 February 2010

\section{References}

1. CDC: FastStats Atlanta: Centers for Disease Control and Prevention 2006.

2. WHO: World Health Statistics 2009 Geneva: World Health Organization 2009.

3. WHO: The top 10 causes of death Genève: World Health Organization 2009.

4. Poland A: On rupture of the ureter. Guy's Hospital Reports 1869, 14(85):189-190.

5. Morris H: Hunterian Lectures - Operations on the ureter. British Medical Journal 1868, 1:873-879.
6. Morris HC: Surgical Diseases of the Kidney Philadelphia: Lea Brothers \& Co, 1 1904.

7. Kirchner KF Jr, Rhamy RK, Freeborn WA: Bilateral ureteral injury secondary to single, low velocity gunshot wound. Urology 1981, 18(3):282-3.

8. Presti JC Jr, Carroll PR, MCAninch JW: Ureteral and renal pelvic injuries from external trauma: diagnosis and management. J Trauma 1989, 29(3):370-4.

9. Zufall R: Traumatic avulsion of the upper ureter. J Urol 1961, 85:246-8.

10. Lynch TH, Martinez-Pineiro L, Plas E, Serafetinides E, Turkeri L, Santucci RA, Hohenfellner M: EAU guidelines on urological trauma. Eur Urol 2005, 47(1):1-15.

11. Best $C D$, Petrone P, Buscarini M, Demiray S, Kuncir E, Kimbrell B, Asensio JA: Traumatic ureteral injuries: a single institution experience validating the American Association for the Surgery of Trauma-Organ Injury Scale grading scale. J Urol 2005, 173(4):1202-5.

12. Srinivasa RN, Akbar SA, Jafri SZ, Howells GA: Genitourinary trauma: a pictorial essay. Emerg Radiol 2009, 16(1):21-33.

13. Palmer LS, Rosenbaum RR, Gershbaum MD, Kreutzer ER: Penetrating ureteral trauma at an urban trauma center: 10-year experience. Urology 1999, 54(1):34-6

14. Narath P: The hydromechanics of calyx renalis. J Urol 1940, 43:145-176.

15. Weiss RM: Ureteral function. Urology 1978, 12(2):114-33.

16. Cass AS: Ureteral contusion and delayed necrosis from gunshot injury. Urology 1978, 12(2):195-6.

17. Tezval H, Tezval M, von Klot C, Herrmann TR, Dresing K, Jonas $U$, Burchardt M: Urinary tract injuries in patients with multiple trauma. World J Urol 2007, 25(2):177-84

18. Narath P: The physiology of the renal pelvis. Urology Edited by Anonymous Philadelphia: WB Sauders 1954, 61-108.

19. Pumphrey JD, Joslin AH, Lich R Jr: Missile wounds of the ureter. J Trauma 1962, 2:89-95.

20. Cass AS: Ureteral contusion with gunshot wounds. J Trauma 1984, 24(1):59-60.

21. McDonald WB, McLeod DG: Low-velocity gunshot injury to ureter. Urology 1978, 11(2):173-4.

22. Selikowitz SM: Penetrating high-velocity genitourinary injuries. Part I. Statistics mechanisms, and renal wounds. Urology 1977, 9(4):371-6.

23. Selikowitz SM: Penetrating high-velocity genitourinary injuries. Part II: Ureteral, lower tract, and genital wounds. Urology 1977, 9(5):493-9.

24. Rohner JT Jr: Delayed ureteral fistula from high velocity missiles: report of 3 cases. J Urol 1971, 105(1):63-4.

25. Stutzman RE: Ballistics and the management of ureteral injuries from high velocity missiles. J Urol 1977, 118(6):947-9.

26. Borden Institute (U.S.): Emergency war surgery: 3rd U.S. revision Washington DC: Office of the Surgeon General U.S. Army, Borden Institute, Walter Reed Army Medical Center 2004.

27. Evans RA, Smith MJ: Violent injuries to the upper ureter. J Trauma 1976, 16(7):558-61.

28. Kotkin L, Brock JW: Isolated ureteral injury caused by blunt trauma. Urology 1996, 47(1):111-3.

29. Reznichek RC, Brosman SA, Rhodes DB: Ureteral avulsion from blunt trauma. J Urol 1973, 109(5):812-6.

30. Brandes S, Coburn M, Armenakas N, McAninch J: Diagnosis and management of ureteric injury: an evidence-based analysis. BJU Int 2004, 94(3):277-89.

31. Obenauer $\mathrm{S}$, Plothe $\mathrm{KD}$, Ringert $\mathrm{RH}$, Heuser M: Imaging of genitourinary trauma. Scand J Urol Nephrol 2006, 40(5):416-22.

32. Mulligan JM, Cagiannos I, Collins JP, Millward SF: Ureteropelvic junction disruption secondary to blunt trauma: excretory phase imaging (delayed films) should help prevent a missed diagnosis. J Urol 1998, 159(1):67-70.

33. Beckly DE, Waters EA: Avulsion of the pelvic-ureteric junction-a rare consequence of non-penetrating trauma. Br J Radiol 1972, 45(534):423-6.

34. Perez-Brayfield MR, Keane TE, Krishnan A, Lafontaine P, Feliciano DV, Clarke HS: Gunshot wounds to the ureter: a 40-year experience at Grady Memorial Hospital. J Urol 2001, 166(1):119-21.

35. Bright TC, Peters PC: Ureteral injuries due to external violence: 10 years' experience with 59 cases. J Trauma 1977, 17(8):616-20.

36. Carlton EC Jr, Scott RJ, Guthrie AG: The initial management of ureteral injuries: a report of 78 cases. J Urol 1971, 105(3):335-40. 
37. Holden S, Hicks CC, O'Brien DP, Stone HH, Walker JA, Walton KN: Gunshot wounds of the ureter: a 15-year review of 63 consecutive cases. J Urol 1976, 116(5):562-4.

38. Peterson NE, Pitts JC: Penetrating injuries of the ureter. J Urol 1981, 126(5):587-90.

39. Ambiavagar R, Nambiar R: Traumatic closed avulsion of the upper ureter. Injury 1979, 11(1):71-6.

40. The American Association for the Surgery of Trauma. http://www.aast org/Library/TraumaTools/InjuryScoringScales.aspx\#ureter.

41. Steers WD, Corriere NJ Jr, Benson GS, Boileau MA: The use of indwelling ureteral stents in managing ureteral injuries due to external violence. $J$ Trauma 1985, 25(10):1001-3.

42. Azimuddin K, Milanesa D, Ivatury R, Porter J, Ehrenpreis M, Allman DB: Penetrating ureteric injuries. Injury 1998, 29(5):363-7.

43. Elliott SP, MCAninch JW: Ureteral injuries: external and iatrogenic. Urol Clin North Am 2006, 33(1):55-66, Vl.

44. Brown DJ, Martindale AD: Urinary Tract Trauma - Diagnosis and management. Trauma 2008, 10(1):5-11.

45. Safir MH: Management of complex violent trauma to the upper urinary tract. Trauma 1999, 1(4):323-339.

46. Eickenberg HU, Amin M: Gunshot wounds to the ureter. J Trauma 1976, 16(7):562-5.

47. Weinberg S: Injuries to the ureter. The Ureter New York: SpringerVerlagBergmann H, 2 1981, 427-448.

48. Pitts JC, Peterson NE: Penetrating injuries of the ureter. J Trauma 1981 , 21(11):978-82.

49. Walker JA: Injuries of the ureter due to external violence. J Urol 1969, 102(4):410-3

50. Christenson P, O'Connell KJ, Clark M: Ballistic ureteral trauma: a comparison of high and low velocity weapons. Contemp Surg 1983, 23:45-50.

51. Velmahos GC, Degiannis E: The management of urinary tract injuries after gunshot wounds of the anterior and posterior abdomen. Injury 1997, 28(8):535-8.

52. Fisher S, Young DA, Malin MJJ, Pierce MJ Jr: Ureteral gunshot wounds. J Urol 1972, 108(2):238-9.

53. Ghali AM, El Malik EM, Ibrahim Al, Ismail G, Rashid M: Ureteric injuries: diagnosis, management, and outcome. J Trauma 1999, 46(1):150-8,

54. Khashu BL, Seery WH, Smulewicz JJ, Rothfeld SH: Gunshot injuries to ureter. Urology 1975, 6(2):182-6.

55. Lankford R, Block NL, Politano VA: Gunshot wounds of the ureter: a review of 10 cases. J Trauma 1974, 14(10):848-52.

56. McGinty DM, Mendez R: Traumatic ureteral injuries with delayed recognition. Urology 1977, 10(2):115-7.

57. Rober PE, Smith JB, Pierce MJ Jr: Gunshot injuries of the ureter. J Trauma 1990, 30(1):83-6.

58. Salvatierra O Jr, Bucklew WB, Morrow JW: Penetrating ureteral injuries. Surg Gynecol Obstet 1969, 128(3):591-6.

59. Spirnak JP, Persky L, Resnick Ml: The management of civilian ureteral gunshot wounds: a review of 8 patients. J Urol 1985, 134(4):733-6.

60. al-Ali M, Haddad LF: The late treatment of 63 overlooked or complicated ureteral missile injuries: the promise of nephrostomy and role of autotransplantation. J Urol 1996, 156(6):1918-21.

61. Archbold JA, Barros d'sa AA, Morrison E: Genito-urinary tract injuries of civil hostilities. Br J Surg 1981, 68(9):625-31.

62. Vuckovic I, Tucak A, Gotovac J, Karlovic B, Matos I, Grdovic K, Zelic M: Croatian experience in the treatment of 629 urogenital war injuries. $J$ Trauma 1995, 39(4):733-6.

63. Dagash H, Sen S, Chacko J, Karl S, Ghosh D, Parag P, Mackinnon AE: The appendix as ureteral substitute: a report of 10 cases. J Pediatr Urol 2008, 4(1):14-9.

64. Sonmez K, Karabulut R, Turkyilmaz Z, Karakus SC, Basaklar AC: Bilateral ureteropelvic junction disruption in a 5-year-old boy. J Pediatr Surg 2008, 43(10):e35-7.

65. Medina JJ, Cummings JM, Parra RO: Repair of ureteral gunshot injury with appendiceal interposition. J Urol 1999, 161(5):1563.

66. Fernandez Fernandez A, Soria Ruiz S, Gomez Martinez I, Gil Fabra J, Martinez Castellanos F, Otero Mauricio G: Blunt traumatic rupture of the high right ureter, repaired with appendix interposition. Urol Int 1994, 53(2):97-8
67. Estevao-Costa J: Autotransplantation of the vermiform appendix for ureteral substitution. J Pediatr Surg 1999, 34(10):1521-3.

68. Richter F, Stock JA, Hanna MK: The appendix as right ureteral substitute in children. J Urol 2000, 163(6):1908-12.

69. Seiler RK, Filmer RB, Reitelman C: Traumatic disruption of the ureteropelvic junction managed by ileal interposition. J Urol 1991, 146(2):392-5.

70. Benson MC, Ring KS, Olsson CA: Ureteral reconstruction and bypass: experience with ileal interposition, the Boari flap-psoas hitch and renal autotransplantation. J Urol 1990, 143(1):20-3.

71. Boxer RJ, Fritzsche P, Skinner DG, Kaufman JJ, Belt E, Smith RB, Goodwin WE: Replacement of the ureter by small intestine: clinical application and results of the ileal ureter in 89 patients. J Urol 1979, 121(6):728-31.

72. Kochakarn $\mathrm{W}$, Tirapanich $\mathrm{W}$, Kositchaiwat S: lleal interposition for the treatment of a long gap ureteral loss. J Med Assoc Thai 2000, 83(1):37-41.

73. Hardy JD: High ureteral injuries. Management by autotransplantation of the kidney. JAMA 1963, 184:97-101.

74. Gil-Vernet JM: Descent of the right renal vein. J Urol 1978, 120(6):668-70

75. Bodie B, Novick AC, Rose M, Straffon RA: Long-term results with renal autotransplantation for ureteral replacement. J Urol 1986, 136(6):1187-9.

76. Kram HB, Ocampo HP, Yamaguchi MP, Nathan RC, Shoemaker WC: Fibrin glue in renal and ureteral trauma. Urology 1989, 33(3):215-8.

77. Kram HB, Reuben BI, Fleming AW, Shoemaker WC: Use of fibrin glue in hepatic trauma. J Trauma 1988, 28(8):1195-201.

78. Shekarriz B, Stoller ML: The use of fibrin sealant in urology. J Urol 2002, 167(3):1218-25.

79. Detweiler MB, Detweiler JG, Fenton J: Sutureless and reduced suture anastomosis of hollow vessels with fibrin glue: a review. J Invest Surg 1999, 12(5):245-62.

80. Kumar U, Dickerson A, Sakamoto K, Albala DM, Turk TM: Effects of fibrin glue on injured rabbit ureter. J Endourol 2001, 15(2):205-7.

81. Fraga GP, Borges GM, Mantovani M, Ferreira U, Laurito TL, Netto RN Jr: Penetrating ureteral trauma. Int Braz J Urol 2007, 33(2):142-8, discussion 149-50.

82. Madhok BM, Duttaroy DD, Desai R, Yeluri S: Ureteric injury caused by a penetrating arrow. J Trauma 2007, 63(1):E17-8.

83. Kunkle DA, Kansas BT, Pathak A, Goldberg AJ, Mydlo JH: Delayed diagnosis of traumatic ureteral injuries. J Urol 2006, $176(6$ Pt 1):2503-7.

84. Akay AF, Girgin S, Akay H, Sahin H, Bircan MK: Gunshot injuries of the ureter: one centre's 15-year experience. Acta Chir Belg 2006, 106(5):572-7.

85. Carver BS, Bozeman CB, Venable DD: Ureteral injury due to penetrating trauma. South Med J 2004, 97(5):462-4.

86. Elliott SP, MCAninch JW: Ureteral injuries from external violence: the 25year experience at San Francisco General Hospital. J Urol 2003, 170(4 Pt 1):1213-6.

87. Hudolin T, Hudolin I: Surgical management of urogenital injuries at a war hospital in Bosnia-Hrzegovina, 1992 to 1995. J Urol 2003, 169(4):1357-9.

88. Pearlstein DP, Brandt M, Introcaso JH, Shah M, Martin T, Sulkowski RJ: Penetrating trauma causing partial disruption of a duplicated ureter: case report. J Trauma 2001, 50(4):755-8.

89. Kennedy F, Sharif S, Hammerstead H, Martin J: Gunshot wound to a duplicate ureter: successful treatment with ureteroureterostomy. J Trauma 2000, 49(1):149-51.

90. Powell MA, Nicholas JM, Davis JW: Blunt ureteropelvic junction disruption. J Trauma 1999, 47(1):186-8

91. Medina D, Lavery R, Ross SE, Livingston DH: Ureteral trauma: preoperative studies neither predict injury nor prevent missed injuries. J Am Coll Surg 1998, 186(6):641-4.

92. Tucak A, Petek Z, Kuvezdic H: War injuries of the ureter. Mil Med 1997, 162(5):344-5.

93. Marekovic Z, Derezic D, Krhen I, Kastelan Z: Urogenital war injuries. Mil Med 1997, 162(5):346-8.

94. Velmahos GC, Degiannis E, Wells M, Souter I: Penetrating ureteral injuries: the impact of associated injuries on management. Am Surg 1996, 62(6):461-8.

95. Soria Ruiz JS, Fernandez Fernandez A, Gomez Martinez I, Martinez Castellanos F, Cabezudo Hernando I, Virto Bajo J, Otero Mauricio G: [Ureteral lesions caused by external trauma: diagnosis and treatment]. Arch Esp Urol 1995, 48(2):123-7. 
96. Brandes SB, Chelsky MJ, Buckman RF, Hanno PM: Ureteral injuries from penetrating trauma. J Trauma 1994, 36(6):766-9.

97. Wazzan W, Azoury B, Hemady K, Khauli RB: Missile injury of upper ureter treated by delayed renal autotransplantation and ureteropyelostomy. Urology 1993, 42(6):725-8.

98. Boone TB, Gilling PJ, Husmann DA: Ureteropelvic junction disruption following blunt abdominal trauma. J Urol 1993, 150(1):33-6.

99. Campbell WE Jr, Filderman PS, Jacobs SC: Ureteral injury due to blunt and penetrating trauma. Urology 1992, 40(3):216-20.

100. Cofer BR, Kaufman PN, Nussbaum MS, Cirulli C: Penetrating injury of a duplicated ureter: case report. J Trauma 1991, 31(1):140-2.

101. Guerriero W, Harrison C: Ureteral injury due to external violence: 49 cases over 5 years. World J Urol 1990, 7(4):214-217.

102. Franco I, Eshghi M, Schutte H, Park T, Fernandez R, Choudhury M, Addonizio JC: Value of proximal diversion and ureteral stenting in management of penetrating ureteral trauma. Urology 1988, 32(2):99-102.

103. Beamud-Gomez A, Martinez-Verduch M, Estornell-Moragues F, OlagueRos R, Garcia-lbarra F: Rupture of the ureteropelvic junction by nonpenetrating trauma. J Pediatr Surg 1986, 21(8):702-5.

104. Cecconi DR Jr, Lloyd L, Hawasli A, DiLoreto R: Bilateral transection of ureters secondary to gunshot wound to abdomen. J Trauma 1986, 26(10):938-40.

105. Grizic AM, Marszalek WW: Pathogenesis and management of ureteric injuries. S Afr Med J 1985, 68(11):811-4.

106. Starinsky R, Melzer M, Modai D, Pajewski M: Blunt abdominal trauma with unrecognized urinary tract injury. Isr J Med Sci 1984, 20(5):401-4.

107. Cass AS: Blunt renal pelvic and ureteral injury in multiple-injured patients. Urology 1983, 22(3):268-70.

108. Drago JR, Wisnia LG, Palmer JM, Link DP: Bilateral ureteropelvic junction avulsion after blunt abdominal trauma. Urology 1981, 17(2):169-71.

109. Laberge I, Homsy YL, Dadour G, Beland G: Avulsion of ureter by blunt trauma. Urology 1979, 13(2):172-8.

110. Liroff SA, Pontes JE, Pierce MJ Jr: Gunshot wounds of the ureter: 5 years of experience. J Urol 1977, 118(4):551-3.

111. Rabinowitz R, Price SE, M MMJ, Barnhouse DH, Johnson SH: Isolated ureteral injury secondary to transperitoneal stab wound. J Trauma 1976, 16(2):164-8.

112. Heath AD, May A: Bilateral avulsion of the upper ureters. Br J Urol 1975, 47(4):386.

113. Johnson JM, Chernov MS, Cloud DT, Linkner LM, Dorman GW, Trump DS: Bilateral ureteral avulsion. J Pediatr Surg 1972, 7(6):723.

114. Del Villar RG, Ireland GW, Cass AS: Ureteral injury owing to external trauma. J Urol 1972, 107(1):29-30

115. Slater RB, Kirkpatrick JR: A case of closed injury of the upper ureter. $\mathrm{Br} J$ Urol 1971, 43(5):591-7.

116. Halverstadt DB, Fraley EE: Avulsion of the upper ureter secondary to blunt trauma. Br J Urol 1967, 39(5):588-93.

117. Ainsworth T, Weems WL, Merrell HWJ: Bilateral ureteral injury due to nonpenetrating external trauma. J Urol 1966, 96(4):439-42.

118. Fruchtman B, Newman H: Upper Ureteral Avulsion Secondary to NonPenetrating Injury. J Urol 1965, 93:452-4.

119. Stone $\mathrm{HH}$, Jones $\mathrm{HQ}$ : Penetrating and nonpenetrating injuries to the ureter. Surg Gynecol Obstet 1962, 114:52-6.

doi:10.1186/1757-7241-18-6

Cite this article as: Pereira et al: A review of ureteral injuries after external trauma. Scandinavian Journal of Trauma, Resuscitation and Emergency Medicine 2010 18:6.

\section{Submit your next manuscript to BioMed Central and take full advantage of:}

- Convenient online submission

- Thorough peer review

- No space constraints or color figure charges

- Immediate publication on acceptance

- Inclusion in PubMed, CAS, Scopus and Google Scholar

- Research which is freely available for redistribution

Submit your manuscript at www.biomedcentral.com/submit
Ciomed Central 